\title{
Analisis Pemilihan Kepala Desa Serentak terhadap Demokrasi Lokal di Desa Tanjung Kabupaten Aceh Tamiang
}

\section{Analysis of Village Head Elections Simultaneously towards Local Democracy in Tanjung Village, Aceh Tamiang Regency}

\author{
Ramadani1)*, Irwan Nasution $^{1)}$ \& Usman Tarigan ${ }^{2)}$ \\ 1) Program Studi Ilmu Pemerintahan, Fakultas Ilmu Sosial dan Ilmu Politik \\ Universitas Medan Area, Indonesia \\ 2) Program Studi Administrasi Publik, Fakultas Ilmu Sosial dan Ilmu Politik \\ Universitas Medan Area, Indonesia
}

Diterima: Mei 2019; Disetujui: Juni 2019; Dipublish: Juni 2019

\begin{abstract}
Abstrak
Pemilihan Kepala desa serentak di pilih langsung oleh penduduk desa warga Negara Republik Indonesia yang memenuhi persyaratan dengan masa jabatan 6 tahun terhitung sejak tanggal pelantikan. Masyarakat desa Tanjung dengan jumlah penduduk hampir 2000 lebih penduduk nya, yang memiliki berbagai suku ras masing-masing. Dalam pemilihan kepala desa harus adanya dukungan dan partisispasi masyarakat desa Tanjung untuk dapat menentukan siapa yang berhak menjabat sebagai kepala desa tersebut. Mengapa dibuat seperti itu supaya masyarakat bebas dan berhak dalam memilih pemimpin yang di inginkan. Pemilihan kepala desa di dukung oleh penduduk desa Tanjung dan atas kerja samanya dengan panitia penyelenggara pemilihan kepala desa. Untuk menjadi calon kepala desa harus memenuhi syarat-syarat yang telah di tetapkan supaya kinerja kepala desa bisa lebih maksimal dan lebih mengetahui aturan-aturannya.
\end{abstract}

Kata Kunci: Analisis, Pemilihan Kepala Desa, Demokrasi local

\begin{abstract}
The election of the Village Head shall be directly elected by the villagers of the Republic of Indonesia who meet the requirements with a term of office of 6 years from the date of inauguration. The community of Tanjung village with a population of nearly 2000 more of its inhabitants, Yang has various racial tribes respectively. In the election of the village head there should be support and participation of the Tanjung village community to determine who is eligible to serve as the village head. Why is it made so that the public is free and entitled to choose the desired leader. The election of the village head is supported by the villagers of Tanjung and for his cooperation with the organizing committee of the village head election. To become a candidate the village head must meet the conditions that have been set so that the performance of the village head can be more leverage and better know the rules.
\end{abstract}

Keywords: Analysis, Village Head Elections, Local Democracy

How to Cite: Ramadani. Nasution, I. \& Tarigan, U. (2017). Analisis Pemilihan Kepala Desa Serentak terhadap Demokrasi Lokal di Desa Tanjung Kabupaten Aceh Tamiang. PERSPEKTIF, 7 (2): 40-45

${ }^{*}$ Corresponding author: ISSN 2085-0328 (Print)

E-mail: ramadani12@gmail.com 


\section{PENDAHULUAN}

Desa dibentuk atas prakarsa masyarakat dengan memperhatikan asal-usul desa dan kondisi sosial budaya masyarakat setempat.pembentukan desa harus memenuhi persyaratan diantaranya jumlah penduduk, luas wilayah, bagian wilayah kerja, perangkat, serta sarana dan prasarana pemerintahan. Pembentukan desa dapat berupa penggabungan beberapa desa,atau bagian desa yang bersandingan,atau pemekaran desa dari satu desa menjadi dua desa atau lebih, atau pembentukan desa diluar desa yang telah ada.Pemekaran dari satu desa menjadi dua desa atau lebih ini dapat dilakukan setelah mencapai paling sedikit 5 (lima) tahun penyelenggaraan pemerintahan desa.desa yang kondisi masyarakat dan wilayahnya tidak memenuhi persyaratan dapat dihapus atau digabung. salah satu persyaratan pembentukan desa yaitu adanya pemerintah desa, Pemerintah Desa terdiri dari kepala desa dan perangkat desa. Kepala Desa mempunyai tugas penyelenggaraan urusan pemerintahan, pembangunan, dan kemasyarakatan dan dipilih langsung oleh dari penduduk desa Warga Negara Republik Indonesia yang memenuhi persyaratan, dengan masa jabatan 6 (enam) tahun yang dihitung sejak yang bersangkutan dilantik. Kepala Desa yang sudah menduduki jabatan hanya boleh menduduki satu kali masa jabatan berikutnya. Kemudian dalam menjalankan tugasnya, kepala desa pada dasarnya bertanggung jawab kepada rakyat.

Sesuai dengan UU No. 32 Tahun 2004 Desa mempunyai wewenang mengatur dan mengurus urusan masyarakat setempat sesuai dengan asal-usul dan adat istiadatnya. Dalam rangka mengatur urusan masyarakat setempat tersebut desa dapat membuat peraturan desa. Peraturan desa adalah bentuk regulasi yang dikeluarkan pemerintah desa sebagaimana kabupaten membuat peraturan daerah. Peraturan Desa ditetapkan oleh Kepala Desa bersama BPD (Badan Permusyawaratn Desa). Peraturan Desa dibentuk dalam rangka penyelenggaraan pemerintahan desa. Peraturan Desa merupakan penjabaran lebih lanjut dari peraturan Perundang Undangan yang lebih tingg dengan memperhatikan kondisi sosial budaya masyarakat desa setempat. Umumnya minat masyarakat dalam Pemilihan Kepala Desa cukup tinggi untuk ikut berpartisipasi dalam proses pemilihan kepala desa (pilkades), karena sebagian masyarakat tidak ada lagi tekanan dan intimidasi politik dari pihak manapun, namun bagi sebagian masyarakat lain adanya paksaan dari salah satu kandidat calon kepala desa melalui tim suksesnya dengan membagikan kaos dan stiker serta adanya tekanan-tekanan para pembotoh yang hadir dalam pelaksanaan pemilihan berlangsung.

Para pembontoh itu memberikan uang kepada sebagian masyarakat agar memilih calon yang disuruh oleh pembotoh, banyak sekali masyarakat yang mengikuti keinginan para pembotoh untuk memilih salah satu calon karena telah diberikan imbalan sebelum masuk kedalam bilik suara. Selain itu ada juga sebagian masyarakat lainnya memilih calon kepala desa karena memiliki hubungan kekeluargaan dengan salah satu calon.

Selain ikut dalam aktivitas pada pelaksanaan Pilkades (Pemilihan Kepala Desa) menjadi partisipan dalam pelaksanaan pemilihan kepala desa dan menjadi pengamat dalam pelaksanaan pemilihan Kepala Desa, ada juga masyarakat menjadi orang yang apathies terhadap pelaksanaan pemilihan Kepala Desa. Orang apathies tersebut benarbenar tidak peduli tentang pelaksanaan pemilihan kepala desa (Pilkades) baik dari tahap pencalonan maupun tahap pelaksanaan Pemilihan Kepala Desa.

\section{METODE PENELITIAN}

Penelitian ini menggunakan metode deskriptif kualitatif, Menurut Sugiyono (2013) Metode kualitatif adalah cara ilmiah untuk mendapatkan data dengan tujuan dan kegunaan tertentu. Obyek dalam penelitian kualitatif adalah obyek yang alamiah, atau natural setting, sehingga metode penelitian ini sering disebut sebagai metode naturalistic, obyek yang alamiah adalah obyek yang apa adanya, tidak dimanipulasi oleh peneliti sehingga kondisi pada saat peneliti memasuki obyek, setelah berada di obyek dan setelah keluar daro obyek relative tidak berubah.sebagai lawannya dari metode ini adalah metode eksperimen dimana peneliti dalam melakukan penelitian. Dalam penelitian kualitatif, pengumpulan data tidak dipandu oleh teori, tetapi dipandu oleh fakta fakta yang ditemukan pada saat penelitian dilapangan. 


\section{HASIL DAN PEMBAHASAN SYARAT-SYARAT MENJADI KEPALA DESA}

Dalam pasal 44 PP No. 72 Tahun 2005 tentang desa menyebutkan bahwa calon kepala Desa adalah Warga Negara Republik Indonesia yang memenuhi persyartan sebagai berikut: 1) Bertakwa kepada Tuhan yang Maha Esa; 2) Setia kepada Pancasila sebagai Dasar Negara, Undang-Undang Dasar Tahun 1945, dan kepada Negara kesatuan Republik Indonesia, serta pemerintah; 3) Berpendidikan paling rendah tamat Sekolah Lanjutan Tingkat pertama dan/sederajat; 4) Bersedia dicalonkan menjadi Kepala Desa. Dll

Kepala Desa Merupakan pimpinan penyelenggaraan pemerintahan desa berdasarkan kebijakan yang ditetapkan bersama Badan Permusyawaratan Desa (BPD). Masa jabatan kepala desa adalah 6 (enam) tahun, dan dapat diperpanjang lagi untuk satu kali masa jabatan. Kepala Desa memiliki wewenang menetapkan peraturan desa yang telah mendapat persetujuan bersama BPD (Badan Permusyawaratan Desa).

Kepala Desa dipilih secara langsung oleh dan dari penduduk Desa warga Negara Republik Indonesia yang memenuhi persyaratan dengan masa jabatan 6 (enam) tahun terhitung sejak tanggal pelantikan. Kepala Desa dapat menjabat paling banyak 3 (tiga) kali masa jabatan secara berturut-turut atau tidak secara berturut turut. Sedangkan pengisian jabatan kepala desa adat berlaku ketentuan hukum adat di desa adat sepanjang masih hidup.

Dan sesuai dengan perkembangan masyarakat serta prinsip Negara Kesatuan Republik Indonesia yang ditetapkan dalam peraturan Daerah Kabupaten/kota dengan berpedoman pada peraturan pemerintah. Khusus mengenai Kepala Desa dalam Undang Undang diatur agar dilaksanakan secara serentak diseluruh wilayah kabupaten/kota dengan maksud untuk menghindari hal negative dalam pelaksanaannya. Pemilihan Kepala Desa secara serentak mempertimbangkan jumlah desa dan kemampuan biaya pemilihan yang dibebankan pada Anggaran Pendapatan dan Belanja Daerah Kabupaten/Kota sehingga dimungkinkan pelaksanannya secara bergelombang sepanjang diatur dalam peraturan Daerah Kabupaten/Kota.
Jabatan Kepala Desa diisi berdasarkan ketentuan yang berlaku bagi Desa Adat. Dalam hal terjadi kekosongan jabatan Kepala Desa Adat, pemerintah Daerah Kabupaten/Kota dapat menetapkan penjabat yang berasal dari masyarakat Desa Adat yang bersangkutan.

Adapun dalam pemilihan Kepala Desa (Pilkades) memiliki azas yang sama dengan Pemilihan Umum yang berlangsung di Indonesia, yaiyu LUBER. Adapun Pengertian dari azas azas tersebut adalah sebagai berikut : 1) Langsung, Rakyat sebagai pemilih mempunyai hak untuk memberikan suaranya secara langsung sesuai dengan kehendak hati nuraninya, tanpa perantara; 2) Umum, Pemilihan yang bersifat Umum mengandung makna menjamin kesempatan yang berlaku menyeluruh bagi semua Warga Negara, tanpa diskriminasi berdasarkan suku agama, ras dan golongan, jenis kelamin kedaerahan, pekerjaan, dan status sosial; 3) Bebas, Setiap Warga Negara yang berhak memilih bebas menentukan pilihan tanpa tekanan danpaksaan dari siapapun melaksanakan haknya setiap Warga Negara dijamin Keamanannya sehingga dapat memilih sesuai dengan kehendak hati nurani dan kepentingannya; 4) Rahasia, dalam memberikan suara, pemilih dijamin dan dipilihnya tidak akan diketahui oleh pihak manapun dan dengan jalan apapun. Pemilih memberikan suara pada surat suara dengan tidak diketahui oleh orang lain; 5) Jujur, Dalam penyelenggaraan pemilihan Kepala Desa, serta semua pihak yang terlibat secara tidak langsung, harus bersikap dan bertindak jujur sesuai dengan peraturan perundang undangan yang berlaku; 6) Adil, Dalam penyelenggaraan Pemilihan Kepala Desa setiap pemilih dan peserta mendapatkan perlakuan yang sama, serta bebas dari kecurangan pihak manapun.

Tugas, Wewenang, dan Kewajiban Kepala Desa: 1) Memimpin penyelenggaraan pemerintah desa berdasarkan kebijakan yang ditetapkan bersama BPD (Badan Permusyawaratan Desa); 2) Mengajukan Rancangan peraturan desa; 3) Menetapkan peraturan desa yang telah mendapatkan persetujuan bersama BPD; 4) Menyusun dan mengajukan rancangan peraturan desa mengenai APBD Desa untuk dibahas dan ditetapkan bersama BPD (Badan Permusyawaratan Desa); 5) Membina kehidupan masyarakat desa; 6) Membina 
perekonomian Desa; 7) Melaksanakan wewenang lain sesuai dengan peraturan Perundang undangan.

Demokrasi lahir dari bangsa Yunani kuno yang mengedepankan gaya pemerintahan berdasarkan suara rakyat. Kata Demokrasi berasal daru dua suku kata yaitu demos yang berarti rakyat dan -kratein yang berarti memerintah. sehingga dapat kita simpulkan bahwa Demokrasi Lokal adalah rakyat memerintah atau pemerintahan yang sering sekali dikatakan sebagai dari rakyat, oleh rakyat, untuk rakyat. Namun demikian, Demokrasi tersebut cenderung mengarah pada sisterm pemerintahan agresif dan tidak stabil cenderung mengarah pada tirani.

Definisi Analisis menurut Komaruddin, Analisis adalah suatu kegiatan berpikir untuk menguraikan suatu keseluruhan menjadi komponen sehingga dapat mengenal tanda tanda komponen, hubungan satu sama lain dan fungsi masing masing dalam suatu keseluruhan yang terpadu. Dalam kamus Akuntansi Analisis adalah evaluasi terhadap kondisi dari ayat ayat yang berkaitan dengan akuntansi dan alasan alasan yang memungkinkan tentang perbedaan yang muncul.

\section{Pemilihan Kepala Desa}

Kepala Desa dipilih secara langsung oleh dan dari penduduk Desa warga Negara Republik Indonesia yang memenuhi persyaratan dengan masa jabatan 6 (enam) tahun terhitung sejak tanggal pelantikan. Kepala Desa dapat menjabat paling banyak 3 (tiga) kali masa jabatan secara berturut-turut atau tidak secara berturut turut. Sedangkan pengisian jabatan kepala desa adat berlaku ketentuan hukum adat di desa adat sepanjang masih hidup.

Perubahan yang signifikan dalam upaya mewujudkan kemandirian desa adalah perubahan dalam alokasi anggaran oleh pemerintah kabupaten. Struktur pemerintah desa dari kepala dusun tingkat RT dan RW dan tidak diatur dalam SK Bupati. Hasil pengamatan menunjukkan ketua RW di bawah koordinasi kepala dusun demikian juga ketua RT dibawah koordinasi RW. Namun pengisian jabatan ini tdak dilakukan melalui pemilihan hanya ditetapkan dengan surat keputusan Kepala Desa.
Berdasarkan penelitian yang penulis lakukan, Pemilihan Kepala Desa sangat membantu masyarakat desa karena merupakan wadah Demokrasi untuk masyarakat Desa dalam hal kebebasan untuk di pilih atau memilih pemimpin Desa, Untuk memimpin kepemerintahan desa kedepan sesuai dengan hati nurani masyarakat di Desa. Jika dalam pelaksanaan Pilkades terjadi penyimpangan-penyimpangan dan berbagai kecurangan yang dilakukan oleh golongan tertentu untuk mendapatkan jumlah suara terbanyak maka pemilihan kepala desa yang dilaksanakan serentak di belahan dunia dengan biaya yang tidak sedikit ini tidak akan mencapai hasil optimal yang sesuai harapan masyarakat secara mayoritas.

Akibatnya, Pemerintah Demokratis hanya sebagai angan-angan yang tak terwujud bahkan kekacauan terjadi dimana-mana. Secara Umum Pemilihan Kepala Desa yang dilaksanakan denga serentak adalah tujuan yang sama yaitu untuk menciptakan terwujudnya pemerintah yang demokratis. akan tetapi dalam kenyataan masih banyak hambatan dan rintangan yang terjadi. Orangorang yang mencalonkan diri sebagai pemimpin tidak begitu sadar akan tanggung jawab yang mengakibatkan ketidak percayaan rakyat dan anantusia masyarakat terhadap pemilu menjadi berkurang.

Oleh karena itu dapat kita perhatikan dalam pemilihan Kepala Desa sekarang ini masih ada nya keterpaksaan masyarakat untuk memilih calon pemimpin, karena masyarakat masih kurang mengerti atau kita peduli dengan pemilihan tersebut. maka nya banyak yang tidak memilih atau Golput. Seharusnya kita sebagai masyarakt yang lebih tau pasti menginginkan pemimipin yang adil bertanggung jawab dalam menjalani amanah nya sebagai pemimpin. maka di perlukannya Pemilihan Kepala Desa tersebut.

Seperti yang di ungkapkan oleh seorang bapak Amiruddin selaku ketua Panitia Pemilihan Kepala Desa di Desa Tanjung Kab. Aceh Tamiang Tanggal 15 Maret 2017. Beliau Mengatakan: "Dalam Pemilihan Kepala Desa saya selaku ketua panitia nya, panitia sudah lebih awal mempersiapkan apa-apa saja yang dibutuhkan dalam Pemilkades tersebut, dari pembuatan pengumumuan sampai ke pencalonan suara. itu kami lakukan sematamata hanya untuk melihat siapa kah yang 
pantas untuk menjadi Kepala Desa dan bisa bertanggung jawab dalam mengemban amanah tersebut".

Kemudian di tambah lagi oleh Bapak Baharuddin, selaku sekretaris di Desa Tanjung Kab. Aceh Tamiang Tanggal 15 Maret 2017. Beliau mengatakan: "Dalam system Pemilihan Kepala Desa yang demokratis adalah masyarakat ikut dilibatkan dalam tahapantahapan penyelenggaraan pemilihan Kepala Desa. sejak dari pembentukan, pencalonan kepala desa, penyusunan daftar pemilih, sosialisasi, kampanye, hingga hari pemungutan suara, dan penetapan calon kepala desa terpilih. disitulah masyarakat lebih tau bagaimana cara memilih calon kepala desa".

Dari hasil wawancara dengan beberapa informan yang dilakukan dapat diketahui bahwa, pada awal pemungutan suara, pemilih yang datang setelah mendaftarkan diri dipersilahkan untuk menunggu dan setelah di panggil baru diberi kartu suara untuk kemudian menuju bilik suara dan seterusnya. beberapa narasumber berpendapat bahwa prosedur pemanggilan ini yang kemudian menjadikan penumpukan pemilih hingga kemudian pemilih harus menunggu lama untuk memberikan suara dibilik suara. banyaknya pemilih yang harus antri menunggu ini kemudian membuat pemilih yang baru datang malas memberikan suara dan memutuskan untuk pulang.

Dalam Proses perencanaan kerja tersebut, Kepala desa telah melakukan dan membuat program-program yang akan di laksanakan dan dijalankan oleh kepala desa yakni: 1) Dengan mengoptimalkan kinerja perangkat desa yang bertanggung jawab dan tidak menyalahi peraturan perundangundangan yang berlaku tentang penyelenggaraan; 2) Pemerintahan desa, serta meningkatkan pelayanan kinerja peranngkat desa Tanjung dalam melayani kebutuhan masyarakat; 3) Melaksanakan koordinasi antar mitra kerja, serta bekerja sama dan bermusyawarah dalam membuat keputusankeputusan tentang program kerja maupun prioritas pelaksanaan program kerja juga dalam penetapan peraturan-peraturan desa yang harus dibuat dan dilaksankan; 4) Meningkatkan sumber daya manusia agar dapat memanfaat kan sumber daya alam yang ada demi mencapai kesejahteraan masyarakat;
5) Meningkatkan kualitas kesehatan masyarakat untuk melaksanakan pola hidup sehat dan mengoptimalkan serta memelakukan pendampingan peran kader posyandu balita agar tercapai kesehatan masyarakat secara lahir batin.

\section{SIMPULAN}

Proses pemilihan kepala desa yang telah ditetapkan dari tahap persiapan, pencalonan, pemungutan suara, dan penetapan kepala desa yang terpilih. Harus adanya partisipasi dar masyarakat. Proses pelaksanaan pemilihan kepala desa diberikan kebebasan untuk masyarakat supaya mewujudkan ciri-ciri demokrasi seperti yang telah di tetapkan oleh peraturan Undang-undang. Peran Pemerintah Daerah menjadi posisi kunci dalam Pelaksaan Pemilihan Kepala Desa Serentak di Desa Tanjung Kabupaten Aceh tamiang. Karena dalam Pemilihan Kepala Desa Serentak di perlukan Sifat Demokratis dan menjadi ciri khas dari desa tersebut terhadap Demokrasi Lokal yang ada di Desa tersebut. Demokrasi lokal juga berperan penting dalam sebuah desa yang mana kita dapat membedakan dengan desa yang lainnya. Esensi pembaharuan sistem pemilihan kepala desa dalam kerangka demokrasi di Indonesia adalah berkaitan dengan persyaratan, tata cara pencalonan dan pemilihan, dan penyelenggara Pilkades. dan dalam pemilihan kepala desa ini harus mengikut persyaratan yang telah dibuat oleh Panitia dan anggotanya, pemilihan Bersifatb Demokrasi dan Serentak.

\section{DAFTAR PUSTAKA}

19 Tahun 2009 Tentang Pemerintahan Kampung (Bupati Aceh Tamiang).

Adam, (2000). Tentang Dampak Negatif dari penduduk Desa

http://Abuvanzablog.WWordpress.com ite/Panitia Pemilihan Kepala Desa. di unduh tanggal 16 maret 2017.

http://dompa.desa.id/454/KTPS/XXI/2016.

Tahapan-tahapanPemilihan Kepala

Desa Serentak. diunduh 19 Januari 2017.

http://politik-kumpulanundangundang.blogspot.com/2011/14/Demokrasi Desa. diunduh tanggal 20 februari 2016.

http://Wiki.pattiro.org/indek.php.2016/14/Hak dan Kewajiban Masyarakat Dalam Pemilihan Kepala Desa.diunduh tanggal 30 april 2017. 
Kusmanto, H. (2007). Desa Tertekan Kekuasaan. Medan: Bitra Indonesia.

Mahmud, A. (2013). Negara Dengan bentuk Pemerintahan Demokrasi

Mona, (2015). Undang Undang Republik Indonesia Nomor 6 Tahun 2014 tentang DESA dan Peraturan Pelaksanaanya. Yogyakarta: Penerbit Pustaka Mahardika.

Nurcholis, H. (2011). Pertumbuhan dan Penyelenggaraan Pemerintahan Desa. Jakarta: Erlangga.

Pemerintahan Kabupaten Aceh Tamiang, menurut Qanun Kabupaten Aceh Tamiang Nomor

Peraturan Menteri dalam Negeri Republik Indonesia Nomor 82 Tahun 2015 Tentang
Pengangkatan Dan Pemberhentian Kepala Desa.

Peraturan PerUndang-undang:

Sedarmayanti. (2012). Good Governance (Pengaturan Desa Oleh good Governance Desa). Bandung: CV. Mandar Maju.

Undang-undang Republik Indonesia Nomor 6 Tahun 2014 tentang Desa dan Peraturanelaksanaannya.

UU No. 32 Tahun 2004 Desa mempunyai wewenang mengatur dan memgurus urusan masyarakat setempat sesuai dengan asal-usul dan adat istiadatnya. 